\title{
Impact of Insect Resistant Cotton
}

\author{
Ambati Ravinder Raju \\ Division of Crop Production, Central Institute for Cotton Research, Nagpur (M.S.), ICAR,India 440010
}

\begin{abstract}
Boll guard I \& II were introduced in 2002 and 2006 by Mahyco Monsanto with Genetic Engineering Appraisal Committee, Govt. of India. Indian cotton farmers adopted Bt hybrid cotton between 2002-2013 reaching $92 \%$ of the cotton area and $95 \%$ of the production, replacing conventional hybrids/varieties of all the species in both rainfed and irrigated conditions. Bt hybrid cotton was presumed to produce record highest average productivities in India and other major cotton growing countries also in 2007 and 2012 with a decline after 2008 due to excess rains. Farmers invested Rs. 1500-1750/- Acre could prevent 24-28\% cotton yield losses by consuming 2.3 times more fertilizers, $35 \%$ herbicides and $22 \%$ growth regulators. Although it was reported three times returns compared to non Bt cotton due to severe inflation pressure farmers profitability got reduced and went unrest in 2011. Seed producers, marketing companies, input dealers and female labourers were major beneficiaries. Bollworms sprays were reduced to zero but sucking pests sprays were almost doubled with low volume more costly insecticides. The pest management cost remain unchanged in this decade. In conclusion, Bt cotton won the confidence of farmers for its bollworm resistance except refugea regultion. Govt. efforts for price control stabilized margin for farmers but eroded due to escalating weed management and hand picking costs after 2008. Yield gap analysis found $N, Z n, M g$ and B were limiting optimum yields, besides post emergence herbicides, rain water conservation/ supplemental irrigations can break present productivity levels and reduce cost of production. Public sector research agencies should follow Public private partnership model adopted by Gujarat Agriculture University, Surat for conversion Bt Hybrid-6 and 8. They need to meet farmer's expectations by developing transgenic insect and herbicide resistant cotton varieties and prove in farmers fields. Breeders must meet consumer's expectations inorder to compete with polyester fibre to get sustainable demand. Bt hybrid cotton impact on economy, input output efficiencies, reducing cost of production, policies affecting farmers profits, $R \& D$ efforts and BMPs across globe were reviewed.
\end{abstract}

Keywords: Bt hybrid cotton, Cropping systems, Events, Impact, Insect resistant cotton, profitability

\section{Importance in economy.}

Cotton crop covers $7 \%$ cropped area, cotton textile industry contributes $4 \%$ of GDP, $14 \%$ of total industrial product, $20 \%$ of total work force, $17 \%$ of country's exports earning and employment to 40 million people in seed cotton production and 20 million people in finished textile goods. Cotton competes with polyester for lack of durability, wash and wear properties, ultimately reaches consumer as blended textiles and apparels [1],[2]. Bt hybrid cotton covers $92 \%$ of the cotton area planted and $95 \%$ of the cotton production [100], [103].

1.2 Cotton production efficiencies were lowest prior to introduction of Bt hybrid cotton in 5 major cotton growing states, where in some of the states cotton had to compete with Guar and soybean crops due to better market prices offered [3],[4], [100].

1.3 India became unique country in the world which plants largest area of insect resistant transgenic hybrid seeds. India plants cotton in 11.6 million hectares, and produced 35.5 million bales using $3.5 \%$ of fertilizers and $37 \%$ irrigation facilities [4]. After the introduction of Bt hybrid cotton production and productivity registered annual double digit growth rate despite not much increase in area [5]-[12],[100]. However, contradictory conclusions were also came[13]. Record highest lint productivities $\left(\mathrm{t} \mathrm{ha}^{-1}\right)$ were reached in India (0.59), USA (0.98), China(1.26), and Brazil (1.39) declined due to floods in Pakistan (0.61) and Uzbekistan (0.76) in the year 2007. The next best year of production and productivity was 2012-13[103]. Prices started falling in 2007, 2009, 2012 and raise in 2008, 2010-11 also affected cotton textile prices [14],[15]. The cost of production in irrigated north zone was US \$ 620 compared to supplemental irrigated central zone US\$ $548 \mathrm{ha}^{-1}$. Rainfed cotton in central zone was costing US\$ 408 compared to south zone US\$ 566 basically due to higher consumption of inputs and labour cost. Indian cotton was most competitive with record highest 4.7 and 5.8 million bales exports in 2005 and 2006 increased to 12.9 million bales in 2012-13 (Fig.1)[16],[17], [106]. 


\section{Impact of Bt hybrid cotton:}

2.1 Introduction of insect resistant cotton had a phenomenal impact on improving seed cotton yields $24-28 \%$, reducing pesticide consumption $43-50 \%$ and reduced cotton prices by $3 \%$ due to increased production[104]. However, real cost of production was increased due to input and labour costs by inflation[20], [102].

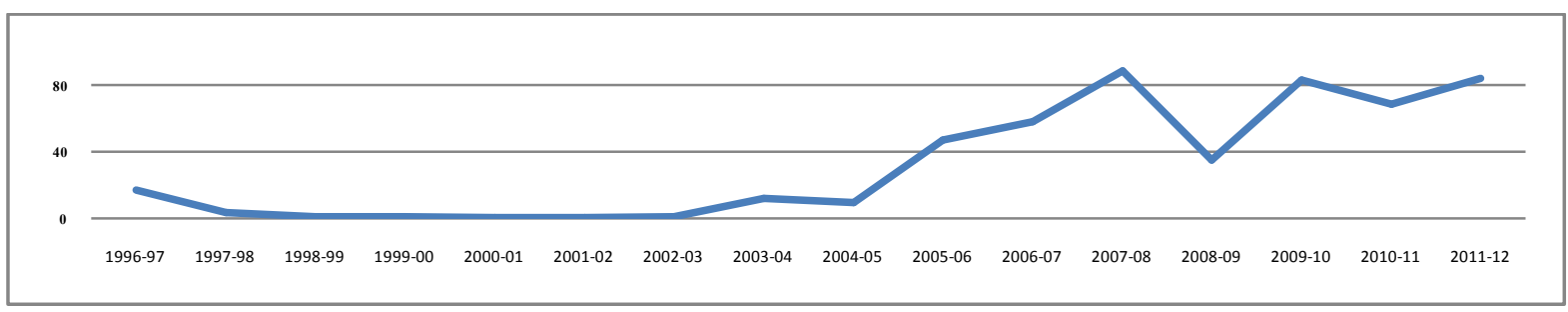

Fig 1. Cotton exports in lakh bales

2.2 Yield increase was as high as $104 \%$ in case of Gujarat, $95 \%$ in Maharashtra and $78 \%$ in case of Andhra Pradesh and less than $15 \%$ only in case of Tamil Nadu state. Pesticide use was reduced by $190 \%$ in Punjab, but increased in three states, due to the emergence of sucking pests [5].

2.3 Bt hybrid cotton adoption increased returns to hired female workers initially for picking followed by weeding after 2008 due to excess rains. This was reflected in the rise incomes of poor and vulnerable landless labourers. Lint yields were improved by $18 \%$ overall in 5 years study during 2003-2008 at Warangal (A.P) [17],[18].

2.4 Insecticide sprayings dropped by 55\%, although predation by non-target pests was rising [19].

2.5 Reduction in $10 \%$ cost of production and $12.5 \%$ cotton prices. Increased $50 \%$ cotton area in middle, $13 \%$ in south Gujarat and 45\% hired labour due to synchronized boll bursting [5].

\subsection{Species shift by Bt cotton}

Adoption of insect resistant cotton initially replaced G. hirsutum cotton $69-90 \%$, G. arboreum cotton $17-4 \%$, G. herbaceum cotton $11-4 \%$ and G. barbadese cotton 3 to $1 \%$ by 2007 [5],[10]. Insect resistant G. hirsutum hybrid cotton area increased 42 to $85 \%$ followed by reduction in G. arboreum 15 to $4 \%$ and G. herbaceum cottons 9 to $5 \%$ by 2010 . This created imbalance in demand and supply of non mill use, organic and surgical cottons and created panic in respective stake holders[28].

\subsection{Bt I \& II events:}

Insect resistant cotton boll gard I was technically approved in 2002 by GEAC, contains Cry 1 Ac Mon 513 synthetic gene, boll gard II contains additional Cry 2 Ab gene approved in May 2006, which was technically designated as MON 15985. Boll gard I offers protection against $H$. armigera, besides this Boll gard II also controls Spodoptera. Major benefit of Boll gard I was reduction in the consumption of chemical pesticides and Boll gard II did not reduced pesticide use further, as farmers seldom apply insecticides against Spodoptera and pink bollworm. Monsanto advocates boll gard II as better protection against pink boll worm [30].

\subsection{Bt toxin Expression:}

Bollgard I \& Bollgard II provide adequate expression of Cry proteins for effective control of Helicoverpa zea in reproductive structures, with the exception of pollen, is a probable avenue for survival of target lepidopteron pests. Impact of this selective feeding on potential resistance development should be explored further [31]. 2.9 Cry toxin concentration was increased up to 80 days after sowing followed by a steep decline. Cry toxin concentration was closely related to the soil moisture content beyond field capacity toxin concentration declined. Split application of $\mathrm{N}$ is an option to enhance cry toxin expression and crop yields under rainfed conditions [32]. Non target fate of Bt Cry toxin release into soil micro flora was found to be minor and safe [33],[34] by peer reviewers.

\subsection{Refugea \& Resistance management.}

Regulatory requirement of refugea is being supplied by seed companies but no farmer is followed [19]. Boll guard II technology was released for management of resistance[30]. 


\subsection{Plant population:}

Indian cotton farmers follow 1.2-1.8 plants $\mathrm{m}^{2}$ with lint yield of 0.35 to 0.5 tha under rainfed conditions of central India, under irrigated western India lint yields were doubled, 5 plants $\mathrm{m}^{2}$ in irrigated north India produced lint yield 0.7 to $0.8 \mathrm{t} \mathrm{ha}^{-1}$ and 1.4 plants $\mathrm{m}^{2}$ in irrigated south India with $1.4-2.2 \mathrm{t} \mathrm{ha}^{-1}$. Planting density of 3.7 plants $/ \mathrm{m}^{2}$ produced significantly higher lint yield $0.75 \mathrm{t} \mathrm{ha}^{-1}$ than 1.85 plants $/ \mathrm{m}^{2} 0.67 \mathrm{t} / \mathrm{ha}$ lint [38]. Although, farmers realized the reduction of Bt hybrid plant size, scope is limited for rising plant density due to cost limitation of transgenic hybrid seeds[35]-[37]. High density Bt hybrid cotton was reported in 2007 and validated in 10,000 hectares demonstration with drip irrigation were made by Nuziveedu Seeds in collaboration with Dept of Agriculture, Maharashtra state in 2012 in Vidarbha region [101].

\section{New challenges.}

3.1 World cotton consumption grew steadily during 1999 to 2007, declined in 2008 due to global economic recession, but lint prices have strengthened further with increasing area of cotton in US and India. Increasing yield per acre while lowering costs of production are critical components of profitability for cotton growers [21]. 3.2 Continuous and increased support for cotton by consumers requires specific qualities in cotton like improved permeability, durability, shrink / wrinkle resistance, shape retention and fire retardation [22].

3.3 Agronomists need to improve productivity through better management practices by application of deficient nutrients and water, besides reducing cost of production through mechanization in weed management and harvesting.

3.4 Public sector hybrids /varieties need to be brought under insect and herbicide resistance umbrella through PPP model adopted by Gujarat Agriculture University, Surat for Hybrids 6 and 8 which can reduce seed cost for farmers [20].

\section{Efforts made by R\&D establishments}

4.0 Cotton invited lot of attention from both national and international agencies, neither input surveys nor impact reviews were targeted in core cotton production areas except farmer's distress. Focused research and development efforts are needed in intensively cotton growing areas to achieve ICAR set targets 1.0 and $2.0 \mathrm{t} \mathrm{ha}^{-1}$ lint with a proven record in farmer's fields respectively under rainfed and irrigated conditions.

4.1 Cotton-wheat system: Bt hybrid cotton replaced major American and desi cotton area in north zone. However, cotton leaf curl virus is severely affecting them except desi cotton. Scientists developed BMPs for Bt hybrid cotton includes better hybrids, populations, nutrient requirement. Machine picking efforts are also in progress by both private and public sector efforts[8],[23]. R\&D establishments must target to improve the productivities in Punjab and Rajasthan productivity is highest i.e. $0.52 \mathrm{t} \mathrm{ha}^{-1}$ lint followed by only $0.48 \mathrm{t} \mathrm{ha}^{-1}$ lint in Haryana state. Bhatinda, Ferozpur, Muktasar and Mansa were most productive districts in Punjab state comprises $89 \%$ area with a productivity $0.78-0.72 \mathrm{tha}^{-1}$ lint [5]. Faridkot with highest productivity of $0.8 \mathrm{tha}^{-1}$ and Sangrur with $0.6 \mathrm{t} \mathrm{ha}^{-1}$ covers only $5 \%$ area of cotton [5]..

4.2 Groundnut-wheat-cotton rotation is popular in western India, covering $22 \%$ of country's cotton area is able to produce $37 \%$ of cotton production with $51 \%$ under hybrid cotton in Gujarat state. Clay loam soils under rainfed conditions average productivity was $0.33 \mathrm{t} \mathrm{ha}^{-1}$ lint compared to state average $0.64 \mathrm{t} \mathrm{ha}^{-1}$ lint average with $45 \%$ canal irrigation [5].

4.3 Bt hybrid cotton-wheat cropping system is becoming more popular due to rationing of farm power and increased the availability of groundwater relatively due to good monsoons between 2003 to 2008, and the development of rain water harvesting [24]. Rain water harvesting and reuse at critical stages produced $0.88 \mathrm{t} / \mathrm{ha}$ lint except 37\% area comprising Bhavanagar, Jamnagar, Junagad and Rajkot districts having average rainfall of $1074 \mathrm{~mm}$ districts were producing $1.2 \mathrm{t} /$ ha lint productivity from ground water irrigation by flood/ drip irrigation method [5],[24].

4.3 Soybean-gram/wheat-cotton: It is a popular crop rotation followed on central India's Vertisols. Cotton is cultivated in 31, 18, 15 and 6\% in Khargone, Khandwa, Dhar and Dewas districts of Madhya Pradesh state with a productivity of 1.1 to 1.5 t/ha lint with irrigation facilities 33 to $80 \%$ [5]. Highest productivity was registered in Khandwa, despite of limited irrigations is due to use of adequate animal manures. Decline in state average yields by $14 \%$ was due to spreading cotton to non conventional areas with lower productivity $0.4-0.75 \mathrm{t} /$ ha lint in Jabhua, Ratlam and Betul districts under limited irrigations of 9-18\% (Fig.2). R\&D is established at Khandwa and Indore under AICCIP. 
4.4 Soybean-gram-cotton rotation is totally replaced with Bt hybrids in central India, Maharashtra state, having $0.29 \mathrm{t} \mathrm{ha}^{-1}$ lint productivity with only $4.2 \%$ irrigation facilities is due to $21 \%$ of the area under sloppy shallow, marginal soils in Yeotmal and Amraoti districts whose lint productivity is $0.18 \mathrm{t} \mathrm{ha}^{-1}$ and often reported as distress districts for which Bt hybrid cotton was blamed as responsible [26],[26]. Farmer's suicides were not due to Bt hybrid cotton as confirmed by researchers from their studies[28]. However, lack of awareness and adoption of rain water conservation, suitable crops and cropping systems, input quantity and usage resulted in highest cost of production in central India. Progressive farmers here were producing $0.5,1.0$ and $1.7 \mathrm{tha}^{-1}$ lint under rainfed, supplemental and drip irrigation, therefore, rain water harvesting also must be explored.

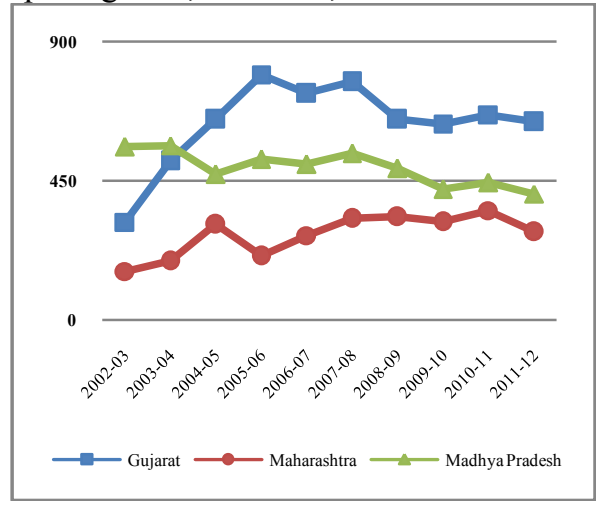

Fig 2. Central zone cotton productivity.

4.5 Jalgoan district is also having sizable area under drip irrigation besides occupying largest cotton area (14\%) in the state along with Yeotmal whose productivity is double [5] of Yeotmal $\left(0.42 \mathrm{tha}^{-1}\right)$ due to sloppy heavy texture soils with moderate rainfall of $600 \mathrm{~mm}$.

4.6 Akola and Jalna districts also produce 1.5 times of Yeotmal i.e. $0.38 \mathrm{t} \mathrm{ha}^{-1}$ lint primarily due to cotton cultivation in deep clayey soils despite of less rainfall than Amraoti district[5].

4.7 Poor agronomical practice like wider sowing, less fertilizer use despite of irrigation facility leading to lower productivity in western Maharashtra.

4.7 Bolangir and Kalahandi districts covers $71 \%$ of Odisha state area with average productivity of $0.38 \mathrm{t} / \mathrm{ha}$ lint, similarly in Ganjam and Koraput districts each with 3\% area. Rayagada district is having $22 \%$ area with best productivity $0.6 \mathrm{t} \mathrm{ha}^{-1}$ lint productivity, similarly, Gajapati district [5].

4.8 Telangana region covers 54\% cotton area of Andhra Pradesh state with 100\% Bt hybrid cotton replacement reduced insecticide consumption to 93\%[5]. However, its main cotton research is concentrated in Lam, Guntur and Nandyal (Kurnool) is mismatching of research investments and ignoring the needs of cotton farmers, ICAR should relook at its establishments with modified targets specific to onfarm research in the heart of cotton belt with limited supplemental irrigations having productivity of $0.48 \mathrm{t} \mathrm{ha}^{-1}$ lint in alluvial sandy loams, red and black soils which also witnessed farmers suicides invited world attention. Nagarjunsagar canal irrigation is fed to loamy soils in Guntur 13\% cotton area with highest productivity of $0.78 \mathrm{t} \mathrm{ha}^{-1}$ lint. Best yields were observed in Warangal and Khammam with by 1.0 and $2.2 \mathrm{t} \mathrm{ha}^{-1}$ lint under rainfed and supplemental irrigations in Bt hybrid cotton with fertilizers 160 and $265 \mathrm{~kg} \mathrm{~N}$ against 113 and $180 \mathrm{~kg} \mathrm{ha}^{-1}$ recommended $\mathrm{N}$ dose, Phosphorous115 and $175 \mathrm{~kg} \mathrm{ha}^{-1}$ and Potash $150 \mathrm{~kg} \mathrm{ha}^{-1}$ against 56 and $90 \mathrm{~kg} \mathrm{ha}^{-1} \mathrm{P}_{2} \mathrm{O}_{5} / \mathrm{K}_{2} \mathrm{O}$ ha respectively, herbicides and micronutrients with a plant population of $0.7-1.0$ plants $\mathrm{m}^{2}[5]$.

4.10 Haveri, Mysore had better productivity of $0.3 \mathrm{t} \mathrm{ha}^{-1}$ lint while only half in Dharwad and Gadag districts covers $67 \%$ cotton area in Karnataka state, whose R \& D is located at Dharwad and irrigated Siruguppa.

4.11 Tamilnadu (T.N.) state which is having only 1 and $4 \%$ of national and zonal cotton area is another example of mismatch of R\&D. Vridhanagar, Madurai and Tutukkodi districts covers 34\% area of Tamilnadu state whose productivity is $0.2 \mathrm{t} \mathrm{ha}^{-1}$ lint, another $25 \%$ area is under Villupuram, Tirunelveli, Salem and Coimbattore districts, whose area is $5-8 \%$ but productivity is $0.32 \mathrm{t} \mathrm{ha}^{-1}$ lint before introduction of Bt hybrid cotton [5]. 


\section{Policies affecting profitability.}

\subsection{Import \& exports of cotton:}

Introduction of Bt hybrid cotton reduced imports around 5 lakh bales restricting to ELS cotton only (Fig.3). Exports were increased 2002 to 2007 reaching 7 million bales with a set back in 2008, 2010 primary cause was govt. policies did not allow exports (Fig.1). Industry and exporter lobby always had clashing interests despite of only $10 \%$ exports which helps to get remunerative prices to farmers. Declined exports were increased after $\mathrm{Bt}$ hybrid cotton era by 12 times reaching as high as 10,270 crores value as the production could not kept pace with spinning and textile mill consumption [14]-[17], [28].

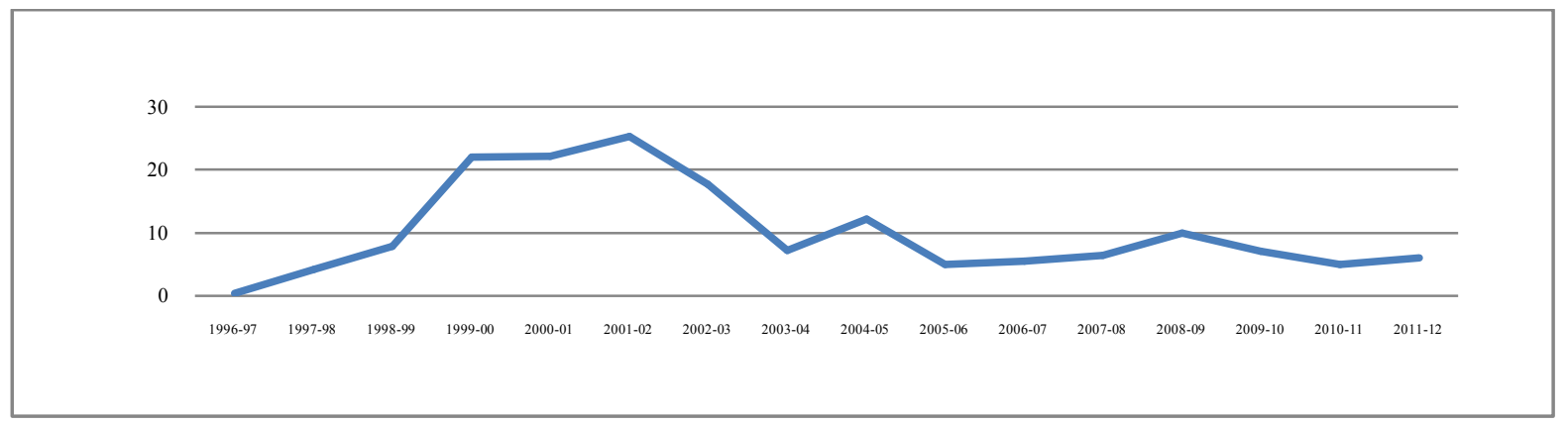

Fig 3. Imports of cotton in lakh bales

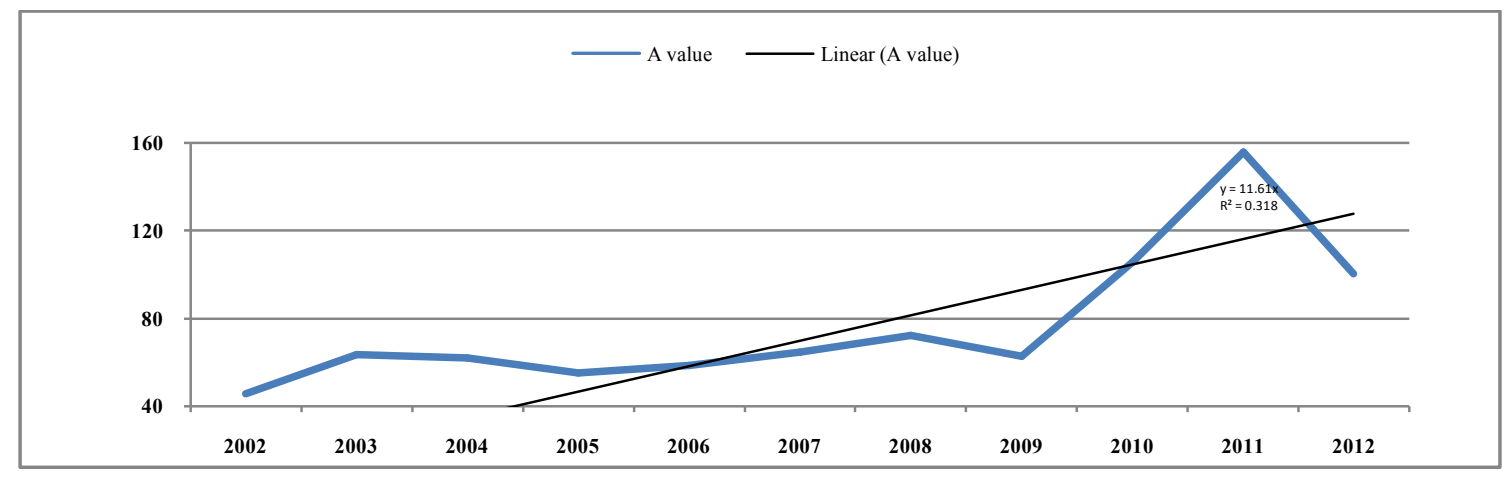

Fig. 4 A value cents/ pound of cotton

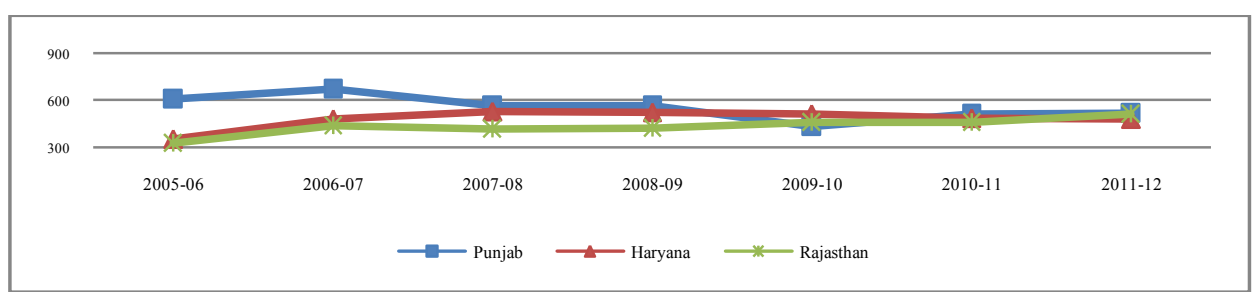

Fig 5. North zone cotton productivity

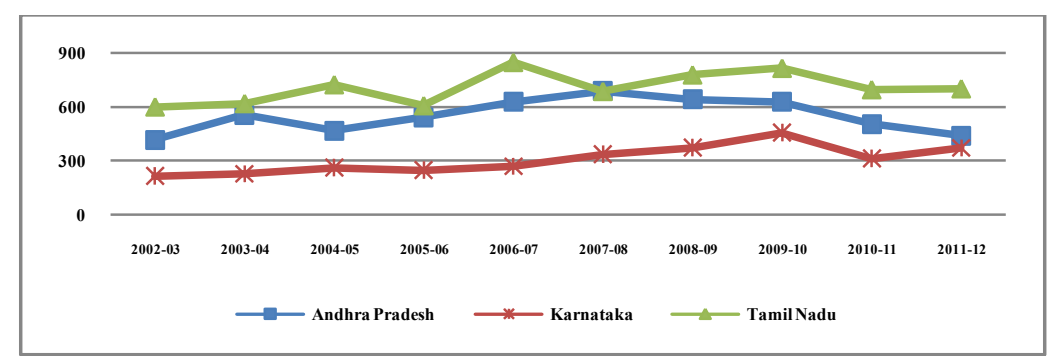

Fig 6. South Zone Cotton Productivity 


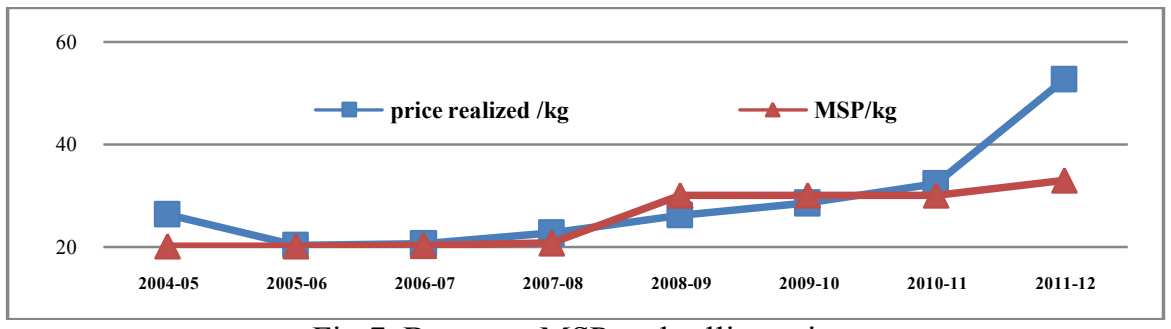

Fig 7. Bt cotton MSP and selling prices

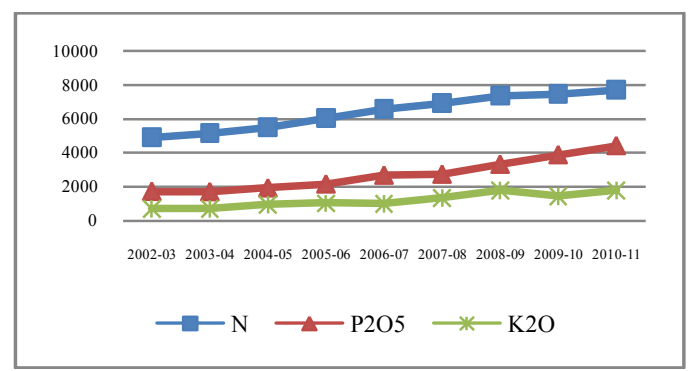

Fig 8. Fertilizer consumption during cotton season

5.2 Extra long staple cotton(ELS): ELS cotton cotton area was little affected by Bt hybrid cotton MRC- 6918 (Bt), RCHB 708 (Bt) which are more susceptible to sucking pests and the current yield levels are lower. ELS cotton hybrids like Chatrapati are performing well in non conventional areas like central India under assured irrigation [1]-[3].

\section{3 plateau in productivity:}

ICAC, chairman and executive director, opined about the prevailing cotton prices in Bt era will add to the cost pressures facing the cotton value chain(Fig.4). Future technology need will be on reducing cost of production[14]-[22]. The productivity in India is slow down 0.57 to $0.52 \mathrm{t} \mathrm{ha}^{-1}$ during 2007-12, 2008-09 in central, a year later in south and north zones (Fig. 5 \& 6), at that time Bt hybrid cotton occupied $90 \%$ of Indian cotton area raises the question about the increase in yield was it really due to Bt hybrid cotton introduction, similar increases were registered in non Bt hybrid cotton areas also. Punjab state productivity increased from 2003-2006, Haryana state 2000-2007 except 23\% declined in 2005-06 a year when Bt hybrid cotton was introduced in north zone (Fig. 5), which was mere co-incidence as it also declined in desi and American cottons in all the north zone states [5]. Four years average found American cotton out yielded $22 \%$ over desi cotton in Haryana but no such differences were observed in Rajasthan which is lowest uniform productive state in north zone. Productivity decline in 2000, 2004-2006 in Madhya Pradesh was due to overall lower rainfall and especially September month, 2005, 2006 in Maharashtra state 2006 in Karnataka state, 2007 in Orissa were noticed. Gujarat state also faced decline in cotton productivity $2006-07$ due to $42 \%$ excess rains over normal, further increased with a continuous decline after 2007 (Fig.2).

\subsection{Prices:}

Forecasting season-average farm prices utilizing the ratio of total ending stocks to use and policy variables will help both planters and traders [40].

5.5 Minimum support price: MSPs were increased by 62\% 2003-12, but the input prices were increased beyond MSPs and farmers in 2011 on agitation to rise it further to Rs. $45 \mathrm{~kg}^{-1}$ to get atleast cost of production. MSP was raised $40 \%$ in $2008-09$ i.e. Rs. $22.5-30 / \mathrm{kg}$ due to the shortage of world cotton stocks resulted in Indian seed cotton price rised to record highest Rs. $69 \mathrm{~kg}^{-1}$ in 2010 (Fig.7). Cotton became most attractive commercial crop to farmers either due to droughts or attractive prices, covered largest area with record highest production followed by export cap in March, 2011 selling prices were dropped to Rs. $34 \mathrm{~kg}^{-1}$ in 2012-13 (Fig. 7). Ten percent of Indian cotton produced is exported, which directly influence the market prices, profitability realized by small and marginal farmers for their entire produce (Fig. 1).

5.6 Cost of production in India varies Rs. $14-24 \mathrm{~kg}^{-1}$ seed cotton in Rajasthan to Tamilnadu during 2007-09 which was basis for MSP [11].

5.6.1 Fertilizer consumption steeply increased from 2005 onwards (Fig. 8)[41]-[43]. Fertilizer input cost was beyond doubled in 2011 after introduction of nutrient based subsidy system[6],[11]. 
5.6.2 Bt hybrid cotton introduction in Gujarat state increased hired labour by $45 \%$ due to synchronization in boll bursting and improved productivity. Changed weather conditions in recent years by droughts followed by continuous rains during 2008-2013 years not only reduced seed cotton yield but raised the weed management cost 2-3 times resulted in lower profitability in cotton cultivation and paved way for wide spread herbicide usage $35 \%$ and introduction of herbicide resistant transgenic cotton in future[43].

5.6.3 Cotton farmers were unhappy on faulty price fixation, procurement system and export caps, expecting Govt. to rise the MSP Rs. 32 to $45 \mathrm{~kg}^{-1}$.

5.6.4 Prices in international market are indicated by A value, which indicates 5 lowest quoted prices was low in 1986 and 2002 only and almost stable between 60-80 cents pound ${ }^{-1}$ (Fig. 4) and steeply raised during 2008, 2010-12 which also responded in Indian cotton prices except during export caps and other irrational decisions[4],[41]-[42].

\section{Reducing costs of production}

6.1 HDPS with non Bt cotton varities:

G. hirsutum, genotype PKV 081, NH 615, Suraj, AKA-7 were found most suitable for high density planting. Large scale mechanized cultivation of HDPS was demonstrated at CICR, Nagpur in 25 acres and transfered the technology in collaboration with local KVKs, Department of Agriculture in 8 districts Vidarbha region and other cotton growing states with pre/ post emergence application of glyphosate + pendimethalin as stale bed technique followed by graminicides + Pyrithiobac Na herbicides during 2011-13. The performance is positive and encouraging results were obtained [35],[36],[101].

\subsection{Weed management:}

Weed management is the next most important issue in Bt hybrid cotton with $10 \%$ to $30 \%$ losses in continuous rains costing Rs. 3000/-Acre. Farmer's of central India were aware about the effectiveness of quizalofop ethyl largely used in soybean and to a limited extent in rotational cotton shifted weed flora towards broad leaf weeds against them Pyrithiobac Na proved its weed control efficiency (85\%) in continuous rains of 2008-2013 [44][48],[74]. In south zone, pendimethalin has been used as pre emergence herbicide after planting of cotton, which effectively controlled the grasses and major broad leaf weeds, perpetuating perennials like Cyperus rotundus, Cynodon doctylon and Echinocloa sp. Celosia argentia, Tridax procumbence, Parthenium and Commelina sp. were serious problem in light soils which were unable to control by Pyrithiobac Na. Trianthema $s p$ and Echinocloasp are serious problem in south and north zone all these can be controlled Trifluralin@1.0 kg a.i.ha ${ }^{-1}$ at germinating stage and post emergence graminicides alongwith pyrithiobac $\mathrm{Na}$ or directed spray of Glyphosate. Weed control in north zone in hot May month with di nitro aniline group of herbicides is difficult as they are volatile and lost by UV radiation. Lay by application of pre emergence cotton herbicides proved effective in both rainfed and irrigated cotton. Post emergence herbicides Quizalofop ethyl, Fenoxoprop methyl and Propquizafop methyl, alongwith Pyrithiobac Na at recommended dose at 20-25 DAS found very effective in controlling weeds in Bt hybrid cotton. Directed spray of Glyphosate on grownup weeds with protective hood in wide spaced Bt hybrid cotton was also quite effective in controlling grownup weeds. Stale seed bed technique of dinitroaniline group pre emergence herbicides alongwith glyphosate as preplant foliage application was quite effective before planting in reducing heavy weed pressure in Bt hybrid cotton followed by post emergence application of Pyrithiobac $\mathrm{Na}$ alone or alongwith graminicides in Bt hybrid cotton based cropping systems proved effective. Pre emergence application of Pendimethalin followed by 2 sprays of roundup or 3 sprays of roundup over the top applications were needed in RR flex cotton for effective weed control. RR flex, Glytol, Liberty link, Wide strike cotton will be very effective with their introduction expected in 2013 with new avenues and challenges in weed management of cotton based cropping systems [44]-[48],[74].

\subsection{Machine picking of cotton}

Synchronization of Bt hybrid cotton maturity created shortage of hired female cotton pickers and more than doubled the picking cost during 2007-10 [18],[19],[49]-[51].

6.3.1 Chinese hand picking machines were popular in north china in ELS irrigated cotton and recently made compulsory as policy measure to ensure better quality and drudgery reduction. They were onfarm tested and found to improve the performance by $25 \%$ after training, with gender neutrality in Nagpur district of Vidarbha region. However, operational difficulties were noticed besides difficulty in walking due to front loaded picking bag compared to manual picking which was only light to moderate work [50],[51]. 
6.3.2 Used John Deere 9935 picking machines from Australia were also introduced in irrigated cotton of Guntur, Andhra Pradesh which damaged cotton branches due to non synchronous maturity of cotton and partial opening of bolls under irrigated conditions during 2008. John deere developed single row 55 HP tractor offset mounted picker whose picking cost and cotton quality is similar to hand picking and large scale feasibility demonstrations including mechanical planting and harvestings were made in Guntur and Hissar under irrigated conditions [59].

6.3.3 CICR, Nagpur also under NATP and TMC projects during 1999-2012 standardized machine parameters for screening cotton genotypes suitable for machine picking, identified cotton genotypes suitable with and without defoliation which can be picked by John deere 9935 cotton picker[60],[61]. This machine can pick approximately one acre per hour with same quality of hand picked cotton but different opinions were expressed [62].

Defoliation protocols were also standardized for irrigated cotton. GTC, CIRCOT, Nagpur developed stationary axial flow pre cleaning system in 4 stages which was commercialized by Bajaj steel for machine picked cotton[60]-[61]. CICR, Nagpur designed a spindle picker head and a stripper suitable for rainfed cotton with synchronized maturity [61].

6.3.4 Dr. PDKV, Akola under TMC MM 2.5 also designed a picker using optical recognition with DC motors for multiple picked asynchronous cotton. Cotton stripper with separate trash cleaning system is probably most suitable future of cotton picking in India[60].

\subsection{BMPs of record highest yields.}

\section{Improving efficiencies}

Vidarbha, Yeotmal: Annual goat pennings improved soil test value from low to high, besides $20 \%$ additional lint yield $\left(0.1 \mathrm{t} \mathrm{ha}^{-1}\right)$ was improved and stabilized over the farmer's practice. A profitable model of Bt hybrid cotton production was evaluated in Yeotmal 2007-10, where cost of production was targeted to improve productivity from 0.4 to 0.67 and $1.0 \mathrm{t} \mathrm{ha}^{-1}$ with additional fertilizers $(58 \mathrm{~kg} \mathrm{~N}, 33 \mathrm{~kg} \mathrm{~K} 20,10 \mathrm{~kg} \mathrm{Zn}, 3 \mathrm{~kg}$ B ha${ }^{1}$ ) and with two supplemental irrigations respectively in rainfed Bt hybrid cotton. Application of pre emergence herbicides as layby or standing crop at $1^{\text {st }}$. intercultures alonwith drilling of basal fertilizers or post emergence herbicide Pyrithiobac $\mathrm{Na}$ application alongwith $2^{\text {nd }}$ interculture when $\mathrm{N}, \mathrm{K}, \mathrm{Zn}, \mathrm{B}$ are drilled can save on hired labour cost of fertilizer and weed management in continuous rains [47],[48]. Bt hybrid cotton yield maximization trial with H6-Bollgard-II was demonstrated in both rainfed and irrigated conditions in Vidarbha region found quite promissing during 2012-14.

7.2 Telangana, Andhra Pradesh: Bt hybrid cotton on an average produced 0.67 to 0.8 and 1 to 1.2 lint tha ${ }^{-1}$ with 150,115 and $75 \mathrm{~kg} \mathrm{~N}, \mathrm{P}_{2} \mathrm{O}_{5}$ and $\mathrm{K}_{2} \mathrm{O}$ fertilizers, pre emergence herbicides alongwith $\mathrm{Zn} 10 \mathrm{~kg} \mathrm{ha}^{-1}$ soil application and one supplemental irrigation in red, sandy and clay loam soils with 1.2 plants $\mathrm{m}^{2}$ matching to the productivity of $100 \%$ canal irrigated cotton of Guntur (A.P).

\subsection{Practices in Brazil:}

Bahia virgin soils of Brazil were brought under soybean/ maize-cotton rotation. Thirty five days of drought reduced $22 \%$ lint yields to $1.23 \mathrm{tha}^{-1}$ in 1998 compared to a normal year of 1999 and 2000 , with $1.5-1.76 \mathrm{tha}^{-}$ ${ }^{1}$ lint with a profitability of Rs. 50, 000/- ha, late drought of 26 days reduced $6 \%$ lint yields to $1.48 \mathrm{tha}^{-1}$ in 2003 . Adequate fertilizers, irrigation and Mepiquat chloride were used 2-3 times at 45 DAS. Rainfed cotton is mechanically cultivated and stripper harvested [64].

\subsection{Practices in China:}

Yellow river valley with $500-800 \mathrm{~mm}$ rainfall, where $41 \%$ area and $35 \%$ production with a lint productivity of $0.81 \mathrm{t} \mathrm{ha}^{-1}$ at a seed rate of $75 \mathrm{~kg} \mathrm{ha}^{-1}$ in Hebei $(75 \%)$, Shanxi and Henan $(50 \%)$ is irrigated through, ground water, often intercropped with corn. Length of growing period is 180 days in cotton-wheat system, with early maturing American varieties, plastic residues and continuous cotton cultivation with higher chemical fertilizers are main issues. Yangtze River valley is having average rainfall of $1030 \mathrm{~mm}$ in sandy loam soils with cotton-wheat/ rape and mustard cropping system, where transplanting two week old cotton seedlings with $26 \%$ area and $21 \%$ production with lowest seed rate of $33 \mathrm{~kg} \mathrm{ha}^{-1}$ produces $0.95 \mathrm{t} \mathrm{ha}^{-1}$ lint. Xinjiang and Gansu provinces are sandy saline soils with low rainfall areas $(<200 \mathrm{~mm})$ with mechanized planting under drip irrigation under mulch with manual picking on large holdings, with a highest productivity of $1.4 \mathrm{t} \mathrm{ha}^{-1}$ lint in high density planting with a seed rate of $111 \mathrm{~kg} \mathrm{ha}^{-1}$ Egyptian cotton grown as single crop. Profitability Rs. 30, 000/- ha ${ }^{-1}$ and some times losses due to $47 \%$ labour cost and $17 \%$ cost only in Xinjiang due to high productivity and mechanization. Chinese cotton is lower strength compared to Australian cotton and comparable to US cotton. China uses $70 \%$ 
water resources in Agriculture and double of fertilizers used by US with only $40 \%$ fertilizer and water efficiency [65].

\subsection{Practices in USA:}

Fiber max 9170 and Deltapine 1044 produced record highest lint yields of $0.89 \mathrm{t} \mathrm{ha}^{-1}$ in 2007 in Texas, Virginia state with drip irrigation [67]. RR Flex cotton helped to adopt more area under conservation tillage due to easier weed management[98].

7.7 Practices in Australia: Australian cotton is produced on alluvial clay loams with $76 \%$ irrigation with a productivity 1.5 to 4 bales ha ${ }^{-1}[67],[68]$.

\section{8 Input use efficiencies}

\section{Major, Secondary and Micronutrients:}

7.8.1 Nitrogen response: Bt hybrid cotton responded $120-180 \mathrm{~kg} \mathrm{~N}^{-1}{ }^{-1}$ in rainfed Vertisols of Andhra Pradesh 2004-2008 [69]-[71],[81]. Hot and dry environmental conditions, and or a lack of existing nutrient deficiency produced non significant response for foliar application of $\mathrm{N}$ and $\mathrm{Zn}$ in Bt II cotton [72]-[76]. Flood irrigated cotton crop yielding $2.8 \mathrm{t} \mathrm{ha}^{-1}$ lint accumulated an average of $180 \mathrm{~kg} \mathrm{~N}, 27 \mathrm{~kg} \mathrm{P}, 167 \mathrm{~kg} \mathrm{~K}, 41 \mathrm{~kg} \mathrm{~S}, 160 \mathrm{~kg} \mathrm{Ca}$, $36 \mathrm{~kg} \mathrm{Mg}, 7 \mathrm{~kg} \mathrm{Na}, 0.89 \mathrm{~kg} \mathrm{Fe}, 0.37 \mathrm{~kg} \mathrm{Mn}, 0.34 \mathrm{~kg} \mathrm{~B}, 0.13 \mathrm{~kg} \mathrm{Zn}$ and $0.051 \mathrm{~kg} \mathrm{Cu} \mathrm{ha}^{-1}$. Lint yield about 1.8 $\mathrm{t} \mathrm{ha}{ }^{-1}$, seed removed $70 \%$ of the $\mathrm{Zn} \mathrm{\&} \mathrm{P,} 52 \%$ of N, $38 \%$ of Cu, $34 \%$ of $\mathrm{Mg}, 21 \%$ of $\mathrm{S}, 17 \%$ of $\mathrm{K}$ and $\mathrm{Fe}, 12 \%$ of $\mathrm{B}$ and only $3 \%$ of $\mathrm{Ca}, \mathrm{Mn}$ and $\mathrm{Na}$. Predictive equations were developed to allow growers to estimate the removal of nutrients given the lint yield measured from their cotton crops [68]. Application of $200 \mathrm{~kg} \mathrm{ha}^{-1} \mathrm{~N}$ and $1.0 \mathrm{~kg} \mathrm{ha}^{-1} \mathrm{~B}$ twice as foliar application in vertisols of Varamin, Iran resulted in the highest lint yield $3.0 \mathrm{t}$ $\mathrm{ha}^{-1}$ and enhanced fiber length, strength and micronaire [77]. B supplied through organic and inorganic manures produced 17 and $28 \%$ significantly higher lint yield than B alone. Manure application had a positive influence on through slow and continued supply of B along with other nutrients to cotton[78].

7.8.2 Red leaf in Bunny Bt hybrid was caused by disruption in carbohydrate metabolism resulted in accumulation of anthocyanin. Red leaves before onset of winter was caused by Jassids and thrips attack while nutrient deficiency was limited to $8-10 \%$ only. Red leaf in early winter was caused due to senescence or nutrient deficiency reduced yields less in Bt hybrid cotton. Shallow and marginal soils are deficient in both water and nutrients, which reduced seed cotton yield $25 \%$ in the absence of fresh leaf growth compared to that of in medium and deep soils[73]. Anthocyanin content was decreased in leaf reddening with increased nutrition and supply of Mg [73].

\subsubsection{Input out put in Bt hybrid cotton.}

Early Bt-adopting farmers realize pesticide reductions of roughly $40 \%$, and yield advantages of $30-40 \%$ with a profit of US \$ $150 \mathrm{ha}^{-1}$. Indian state governments in 2006 established price caps has further increased farmers' profits [79].

\subsubsection{Water use efficiency}

Additional profit of Rs. 14, 000/-ha $\mathrm{h}^{-1}$ was shown by supplemental irrigation by early adopted Bt hybrid cotton farmers in Maharashtra 2004-06 [18],[24],[80]. Higher profitability of N Bt cotton higher over Bt hybrid was due to its reduced duration and susceptible to sucking pests in shallow soils where it was susceptible for red leaf [72],[73].

\subsubsection{Drip irrigation:}

The area under drip irrigation with cotton reached 40,845 ha by 2010 compared to $2 \mathrm{~m}$ ha in other crops in India. Drip irrigation alongwith with 218,115 and $75 \mathrm{~kg} \mathrm{~N}, \mathrm{P}_{2} \mathrm{O}_{5}$ and $\mathrm{K}_{2} \mathrm{O}$ fertilizers in Telangana,Vidarbha and Saurashtra regions of Andhra Pradesh, Maharashtra and Gujarat respectively produced $2.0 \mathrm{t} \mathrm{ha}^{-1}$ lint of Bt hybrid cotton with 1.2 to 2.2 plants $\mathrm{m}^{2}$. RCH 134 produced significantly higher lint yield $0.8 \mathrm{t} \mathrm{ha}^{-1}$ than MRC 6304 and RCH 314 [85],[86]. Linear increase in lint yield registered up to $200 \mathrm{~kg} \mathrm{~N} \mathrm{ha}^{-1}$ with drip Etc 0.8 to Etc 1.0 in drip irrigated Ankur 651 with a water productivity ranged from 0.33 to $0.49 \mathrm{~kg} \mathrm{~m}^{-3}$ at Jodhpur, India. Bt hybrid cotton Ankur 651 and 2534 at 1.65 plants $\mathrm{m}^{2}$ with $150 \mathrm{~kg} \mathrm{~N}^{-1}$ produced $1.0 \mathrm{t} \mathrm{ha}^{-1}$ lint at Bhatinda, Punjab. Dense paired row sowing under drip irrigation, with $75 \%$ irrigation water increased the mean lint yield by $5 \%$ and water use efficiency by $19 \%$. RCH 134 hybrid with 2.5 plants $\mathrm{m}^{2}$ with $188: 75: 75 \mathrm{~N}_{2} \mathrm{P}_{2} \mathrm{O}_{5}$ and $\mathrm{K}_{2} \mathrm{O}$ $\mathrm{kgha}^{-1}$ gave significantly higher lint yield 1.0 and $1.3 \mathrm{t} \mathrm{ha}^{-1}$ at Hisar and Sirsa, Haryana, India under conventional irrigation. Lint yield of $0.7 \mathrm{t} \mathrm{ha}^{-1}$ was recorded at Akola with 125: 62.5: $62.5 \mathrm{~N}, \mathrm{P}_{2} \mathrm{O}_{5}$ and $\mathrm{K}_{2} \mathrm{O} \mathrm{kg} \mathrm{ha}{ }^{-1}$ through drip irrigation [83],[84]. ELS cotton lint yield of $0.9 \mathrm{t} \mathrm{ha}^{-1}$ was recorded with drip irrigation by saving $42 \%$ water with $5.12 \mathrm{~kg} / \mathrm{ha} \mathrm{mm} \mathrm{WUE} \mathrm{at} \mathrm{Coimbatore,} \mathrm{India.} \mathrm{Polytube} \mathrm{drip} \mathrm{irrigation} \mathrm{costed} \mathrm{Rs.} \mathrm{7,} 273 \mathrm{ha}^{-1}$, micro 
tube drip system Rs. 7, $983 \mathrm{ha}^{-1}$ and Rs. 12, $594 \mathrm{ha}^{-1}$ under conventional drip system [82]. Optimal N fertilizer rate was applied, crop $I$ NUE averaged $12.5 \pm 0.2 \mathrm{~kg}_{\text {lint kg }}{ }^{-1}$ crop N uptake. Crop N uptake averaged $247 \mathrm{~kg} \mathrm{~N}$ $\mathrm{ha}^{-1}$ for lint yield $2.27 \mathrm{t} \mathrm{ha}^{-1}$ and crop $i$ NUE $10 \mathrm{~kg} \mathrm{lint} \mathrm{kg}^{-1}$ crop under flood irrigation of Australia [68]. Pakistan drip irrigation system registered $22 \%$ higher lint yields with plant spacing $10 \mathrm{~cm}$ over furrow irrigation and plant spacing $30 \mathrm{~cm}$ with $7.9 \mathrm{~kg} \mathrm{ha}^{-1} \mathrm{~mm}^{-1}$ WUE and water saving of $53 \%$ [68].

\section{Post harvest \& processing}

8.1 Fibre quality: Bt- 121 cotton in Pakistan had better fibre maturity and produced $26 \%$ higher seed cotton yield and $58 \%$ less cotton leaf curl virus infection than all other non Bt cultivars [87]. Yield plateau with increasing micronaire values were observed in US and India with determinate genotypes influenced by farm management practices [88]-[96]. Egyptian cotton yield, micronaire and uniformity were improved by applying $\mathrm{K}$ fertilization at $48 \mathrm{~kg} \mathrm{ha}^{-1}$ combined with spraying cotton plants with chelated zinc at $58 \mathrm{~g} \mathrm{ha}^{-1}$ and also with $\mathrm{P}$ at $1728 \mathrm{~g} \mathrm{ha}^{-1}$ [79],[91],[95],[96]. Yarn properties did not differ for a bale having micronaire $>4.5$ for a given variety grown in one location, yarns produced from $<4.0$, micronaire many of the yarn properties are highly influenced by the fineness, therefore individual bales need to be bar coded for its identification which can give better yarn quality and end product[89]. Roller speed of 110 to 140 RPM coupled with a beater speed of 1000 oscillations per minute can increase the ginning rate by $50-140 \%$ for longer staple cotton with lower ginning cost [97].

\subsection{Seed oil extraction \& oil quality:}

India is a unique country in the world markets seed cotton where farmers looses vegetable cooking oil for day to day needs, besides nutrient rich cake for farm animals and nutrient hunger soils. Localized ginning and oil extraction in village if promoted by NGOs can bring additional $10-15 \%$ profits besides self sufficiency of villages. However, this was a clashing interest to the private ginning industry and investors on ginning and trading who gets lot of bank financing and volume of cotton trade. There is no significant difference in oil percentage and fatty acid composition in Bt hybrids when compared to their non Bt versions [90].

\section{References}

[1]. CITI, Extra Long Staple Cotton Vision Statement 2006 www.simamills.com/docs/ls_ vision.pdf

[2]. Vackayil J., Textile body calls for SPV to promote long staple cotton. The Financial Express. 2007, Monday, 17 ${ }^{\text {th }}$. September.

[3]. Mohanty, S. Cheng F., J. Chaudhary, Assessing the Competitiveness of Indian Cotton Production: A Policy Analysis Matrix Approach. Food and Agricultural Policy Research Institute (FAPRI) at Iowa State University, Food and Agricultural Policy Research Institute (FAPRI) Publications 01/2002; website: www.card.iastate.edu

[4]. Sharma, VP and H. Thaker, Fertilizer Subsidy in India: Who are the Beneficiaries? W.P. No. 2009-07-01 July 2009.

[5]. Barik, A., Cotton statistics at glance. Directorate of Cotton Development, Mumbai and National Centre for Integrated Pest Management, New Delhi. 2010.

[6]. FAI, Fertilizer Policy Govt of India, Ministry of Fertilizers, 2013.http://fert.nic.in/page/fertilizer- policy

[7]. AICCIP, Project Coordinator's Report AICCIP - 10 Oct 2011. Central Institute for Cotton aiccip.cicr.org.in/ CD_11_12/2_PC report. pdf

[8]. Anonymous. Indian cotton production: Current scenario - The Indian Textile Journal 2012. articles/ FAdetails.asp? id=2737 Cached -www.indiantextilejournal.com/

[9]. Choudhary, B. and Gaur, K. Bt cotton in India: A Country Profile. ISAAA Series of Biotech Crop Profiles, 2010. ISAAA: Ithaca, NY.

[10]. Singh, N. B., Revolution in Indian cotton. Directorate of cotton development, Mumbai. 2009. pp 13-1

[11]. DOAC, Annual report 2010-2011 Department of Agriculture and Cooperation, Ministry of Agriculture, Government of India.DOI: 10.1007/s10705-006-9058-2.

[12]. Ramasundaram, P. S. Kurup and J. Samuel, Economic impact of genetically modified cotton in India: Welfare effects and its distribution across states. Abstract No. Oral-25, WCRC-5, Mumbai(India) November, 2011

[13]. Kavitha Kuruganti, Bt cotton and the Myth of enhanced yields. Insight May 30, 2009 vol xiiv no 22 EPW Economic \& Political Weekly. 29-

[14]. Economic survey, Economic Survey 2012-2013 report at Economic Times. Presented economictimes.indiatimes.com/economicsurvey2012.cms

[15]. Economic Times, Cotton exports may remain flat at 100 lakh bales in 2013-14 http://articles.economictimes.indiatimes.com/201309-01/news/41663384 1 bales-natural-fibre-exports-cotton-advisory-board

[16]. ICAC, The new ICAC cotton price Forecasting model. Cotton: Review of the world situation 2007. 60(6):11.

[17]. ICAC, World cotton prices retreat due to slowing demand-Cotton statistics and News, Cotton Association of India, 2012. http://mahacot.com/pdfs/Cai082011-12.pdf

[18]. Subramaniam, A. \& Matin Qaim, The impact of Bt cotton on poor households in rural India, Journal of Development Studies, 2010. 46(2): 295-311.

[19]. Stone, G.D., Field versus Farm in Warangal: Bt cotton, higher yields, and larger questions. World Development, 2010. 39(3):387398.

[20]. Reddy, A.R, Impact of Bt cotton CICR, Nagpur (Unpublished). Personal communication provided to deliver talk on Bt hybrid cotton Nutrients \& weed management by the Author at Mahindra \& Mahindra Agriculture Marketing staff 20/7/ 2013 at Agriculture College, Pune.

[21]. Townsend, T, Cotton yield gains slowing as biotech cotton acreage tapers off. In Proc Cotton economic outlook symposium at the National Cotton Council's Beltwide Cotton Conferences in Orlando 2010.

[22]. Anderson, D. M., Applying technology to address the challenges, WCRC 5(Mumbai), India November, 2011. 
[23]. Raju,A.R.,Mechanization Cotton production CICR, Nagpur tmc.cicr.org.in/pdf/2.3-07-08.pdf PDF file

[24]. Shah, T A. Gulati, H. P, G. Shreedhar, R C Jain, Secret of Gujarat's agrarian miracle after 2000, Review of agriculture. Economic \& Political Weekly, 2009. xiv (52) : 45-56.

[25]. Mishra, S.,Executive summary, Suicide of farmers in Maharashtra (submitted to the government of Maharashtra) Indira Gandhi Institute for Development Studies, Mumbai, 2006., http:// www. igidr. ac. in/suicide/Executive Summary, SFM_IGIDR_ 26 Jan 06 .pdf

[26]. Gandhi, V.P. N.V. Namboodiri, The Adoption and Economics of Bt Cotton in India: Preliminary Results from a Study Indian Institute ofManagement,Ahmedabad, 2006. http://www.iimahd.ernet.in/publications/data/2006-09-04_vgandhi.pdf

[27]. Guillaume, G., Mehta-Bhatt, P. Sengupta, Deb Datta, Bt cotton and farmer suicides in India, Reviewing the evidence, International Food Policy Research Institute, Washington, 2008.

[28]. ICAC,Social impacts of global cotton production icac.International

[29]. www.icac.org/seep/documents/reports/literature_review_july_2008.pdf.

[30]. Foster, D., M. Messmer, R. Baruah and S. S. Patil.,Proc of National Workshop Disappearing Non-GM Cotton-ways forward to maintain to diversity increase availability and ensure quality of non GM cotton seed. U.A.S. Dharwad, $21^{\text {st }}$. June, 2011.

[31]. Rao, C. K. Gene stacked Bollgard II cotton in India.Foundation for biotechnology awareness and education, Bangalore, India 2011. krao@vsnl.com,www.fbae.org,www.fbaeblog.org

[32]. Lindenman, T. J. Fowler, I. N, J. W. Mullins and Sakuntala Sivasupramaniam, Expression of Bollgard I \& Bollgard II Bt proteins in reproductive cotton plant tissues and associated feeding behavior \& survivability of Helicoverpa zea. Monday, November 2, 2009: 10:45 AM Convention Center, Room 405,International Annual Meet Foot prints in the land scape: Sustanability through plant and Soil Science. Fourth Floor/ AnMtgs Absts 2009.54840.

[33]. Blaise.D. and Kranthi, K.R., Cry toxin expression in Bt transgenic cotton hybrids influenced by soil depth and split application of N Abstract No. Oral-19 page 14 WCRC-5, November, 2011.

[34]. Wenke, LIU., Effects of Bt transgenic crops on soil ecosystems. A review of ten years research in China. Frontiers of Agriculture in China 2009. 3(2):190-198.

[35]. Clark, BW; Phillips,TA, JR, Coats Environmental fate and effects of Bacillus thuringiensis (Bt) proteins from transgenic crops: a review. Journal of Agricultural and Food Chemistry, 2005. 53(12): 4643-4653

[36]. Venugopalan,M.V.; Sankaranarayanan,K.; Blaise,D.; Nalayini, P.; Prahraj, C. S.; Gangaiah, B. Bt cotton (Gossypium sp.) in India and its agronomic requirements - Indian Journal of Agronomy 200954 (4): 343-360.

[37]. Venugopalan,M.V.,A.H. Prakash,, K. R. Kranthi, Rachana Deshmukh, M.S. Yadav and N.R. Tandulkar, Evaluation of cotton genotypes for high density planting systems on rainfed vertisols of central India, In Proc WCRC-5. Mumbai (India) November, 2011.

[38]. Mandava MPR and S. Alapati. Bt cotton offers planting at higher planting densities in India Confexwcrc.confex.com/wcrc/2007/techprogram/P1180.HTM Sep 12, 2007.

[39]. Hallikeri, S. S. Pruning and detopping studies in Bt-cotton. In Proc WCRC-5. Mumbai (India) November, 2011.

[40]. Kale N. M., Productivity annual income and indebtedness position: A comparative study of farmers who committed suicides with others. Karnataka Journal of Agricultural Sciences, 2011. 24(3):

[41]. Karaman, S. A. Kocak and G. Tezel. Role of government subsidy programs and markets factors on the determination of cotton prices in Turkey. Concurrent Session 5 Economics production systems., Abstract No. Oral-21 page 15, In Proc WCRC-5. Mumbai (India) November, 2011.

[42]. FAI, "Fertiliser Statistics 2007-08 and Earlier Issues", Fertiliser Association of India, New Delhi 2008.

[43]. India agristat, Statewise fertilizer consumption. Directorate of Economics and statistics, DOAC. Govt. of India,2009. www.indiaagristat.com/ membership.aspx

[44]. Monsanto, Indian Roundup Ready Flex GE cotton to be delayed to 2013 . www. gmo-freeregions.org/gmofree.../india/24522.htmlCached

[45]. Patil, B.C., Evaluation of Targa Super 5EC (Quizalofop ethyl) for the control of grassy weeds in cotton- 2007. wcrc.confex.com

[46]. Nitya and Chinnaswamy,In Proc WCRC-5. Mumbai (India) November, 2011.

[47]. Rao, A.S., In Proc WCRC-5. Mumbai (India) November, 2011.

[48]. Ambati Ravinder Raju and Soniya K.Thakare, Profitability and FUE of Bt cotton based intercropping systems under changing rainfall patterns in Vertisols of India African Journal of Agriculture Research, 2012 8(24):3177-3185.

[49]. Ambati Ravinder Raju, Soniya Thakare, G. Majumdar and P. R. Bharambe, Risk aversion in shallow soils with innovative intercropping systems. J Cotton Res. Dev. 2013, 27 (1):37-44.

[50]. Sunita Chauhan and Ambati Ravinder Raju, Innovative cotton harvesting bags International J of Agricultural Innovations \& Research,2013 2(1):108-111.

[51]. Majumdar, G. Raju, A. R. and Sunita Chauhan, Mechanical picking of cotton Abst No. 163 pp.168. In Proc WCRC-5. Mumbai (India) November, 2011.

[52]. Raju, A. R. and Majumdar, Evaluation of portable cotton picker.International J of Agricultural Innovations \& Research,2013. 2(1):104-107.

[53]. Muthamilselvan, M. K. Rangaswamy and A. Sampathrajan, Feasibility and economic viability of knapsack cotton picker in India. Indian J. Agric. Res. 2007. 41(2):86-91.

[54]. Bilonikar, V.V., Inventor, cotton plucking machine. Team, YS February, 26, yourstory. in /2009/02/v-v-bilonikar-inventor -cottonplucking-machine -2 .

[55]. Patel, M. Amazing story of a stripping machine that revolutionised cotton industry. By Kavita Kanan Chandra Mumbai. The week End Leader, 2012.3(24)June15-21,Barefoot-inventor.html www.theweekendleader.com/Innovation/597/

[56]. Mishra, S.K. B.K. Bennet and B. D. Mc Peek, Cost trade offs of stripper mounted Bur extractors from producers perspective 1997.thinktech. lib.ttu.edu/ttur/bitstream/handle/2346/1825/Cost\%20Trade-Offs.pdf? sequence=1·PDF file

[57]. Nelson, J and S. K. Mishra,B. K. Bennet, Cost benefit analysis bur extractors in cotton ginning. www.aaec.ttu.edu/CERI/NewPolicy/Publications/Beltwide/1996-2000/Cost-Benefit.PDF · PDF file

[58]. Nelson, J and S.K. Mishra,Economic comparison of alternative harvesting systems, Texas TechnicalUniversity,Lubbock,Texas.www.aaec.ttu.edu/Research/Publications/Publications/2000 Beltwide/ cer-00-5.PDF · PDF file

[59]. Nelson, J and S.K. Mishra, A.Brashears, Costs associated with alternative cotton stripper-harvesting systems in Texas. TheJournal of Cotton Science, 2000, 4:70-78. http://journal.cotton. org,

[60]. John deere,Demonstration of mechanized plantingand harvesting (personal communication) 2012.

[61]. Raju,A.R.,Mechanization Colton production CICR, Nagpur tmc.cicr.org.in/pdf/2.3-07-08.pdf · PDF file 
[62]. CPCFM-MERADO, Cotton picking head: basic studies \& design. DST \& CSIR (CMERI) Sponsored MERADO (CMERI) CENTRE FOR ... CICR \& PAU \& CMERI/MERADO-2010 8.2 www.cmeri.res.in/ oth/merado -cpcfm.pdf · PDF file

[63]. CIRCOT, News:Axial Flow Seed Cotton Pre-Cleaner. bpdcircot.com/ press-release/19-press-releases/...press...of-circot-nagpuron-8th-aug-2011

[64]. Baker, K. D., Hughs, S.E., McAlister, D.D., Mackey, J. Quality of spindle-picked cotton. American Society of Agricultural Engineers. 2004. Paper No. 041052.

[65]. Farm, H., 2006. Brazil dryland frontier Farm. 2000-2006 AgBrazil, Inc. ceo@agbrazil.com

[66]. BCI, Better cotton Initiative China, Scoping study executed by Solidaridad, 2010

[67]. Silvertooth, J. C., Recent yield and fiber micronaire tendencies for upland cotton in Arizona. This is part of Arizona Cotton Report, 2001. The University of Arizona College of Agriculture and Life Sciences, index at http://ag.arizona.edu/pubs/crops/az1224/

[68]. Rochester, I. J., Assessing internal crop nitrogen use efficiency in high-yielding irrigated cotton Nutrient Cycling in Agroecosystems, 2011.90 (1): 147-156,

[69]. Rochester, Ian J. Nutrient uptake and export from an Australian cotton field Nutrient Cycling in Agroecosystems, 2007, 77 ( 3): 213 223 ,

[70]. Reddy,P.R.R.; Kumar, B. D., Fertilizer response studies in Bt cotton hybrid Journal of Cotton Research and Development 2010, 24 (1) : 76-77.

[71]. Reddy, P. R. R.; Kumar, B. D.; Gopinath, M.; Rao, L. J. Nitrogen levels and scheduling studies in Bt cotton hybrids. Crop Research (Hisar) 200938 (1/3):61-63 http://www.cropresearch.org

[72]. Sree Rekha M., and T. Pradeep, Agronomic management for Bt cotton under rainfed conditions. Indian Journal of Agricultural Research 2012. March

[73]. Raju, A.R., G. Majumdar, M. K. Meshram and Soniya K. Thakre, What causes Red leaf in Bt hybrid cotton?-Abst No. 162 pp.168. In Proc WCRC-5. Mumbai (India) November, 2011.

[74]. Ambati Ravinder Raju and Soniya K. Thakare., Nutrient management on FUE, red leaf, fibre properties of Bt hybrid cotton(Gossypium hirsutum). Indian Journal of Agronomy, 2012, 57 (4): 13-19.

[75]. Nalayini P and Ravinder Raju A.,Recent advance in weed management. Cotton Research Journal, 2010, 1 (1):18-35.

[76]. Blaise, Venugopal, JV Singh and A. R. Raju., Fertilizer best management practices in cotton Indian Journal of Fertilizes, 2013, 4(2):110-119.

[77]. Raju A.R., Majumdar G. and Reddy A. R., Validation of farm pond size for irrigation during drought. Indian Journal of Agronomy, 2011 56(4): 356-36.

[78]. Rashidi, M. and Gholami, M, Nitrogen and boron effects on yield and quality of cotton International Research Journal of Agricultural Science and Soil Science, 2011,1(4):118-125. @http://www.interesjournals.org/IRJAS

[79]. Janaki, P. and S Meena,, Response of cotton to bio boron and its use efficiency in vertic ustropept soil of Tamil Nadu, India Abstract No. Oral-18 page 13 In Proc WCRC-5. Mumbai (India) November, 2011.

[80]. Sadashivappa, P. and M. Qaim., Bt Cotton in India: Development of benefits and the role of government seed price interventions. Journal of Agro BiotechnologyManagement and Economics, 2009, 12 (2): 3

[81]. Viswanathan, P. K. and N. Lalitha, GM technology and sustainable agriculture future: Empirical evidences from Bt cotton farmers in Maharashtra and Gujarat in India. Gujarat Institute of Development Research, Ahmedabad, India. Journal of Development and Agricultural Economics, 2010, 2(1): 7-17, Available online at http://www.academicjournals.org/JDAE.

[82]. Tayade, A. S., R. R. Gupta, M. K. Meshram and M. V. Venugopalan,Onfarm evaluation of nutrient management based interventions in rainfed cotton production system. Indian J. of Fertilizers, 2011, 7(3):12-17.

[83]. Sankaranarayanan, K, C S Praharaj, P Nalayini, K Bandyopadhyay, N Gopalakrishnan, Climate change and its impact on cotton. Indian Journal of Agricultural Sciences, 2010, 80 (7): 561-75, http://epubs.icar.org.in/ejournal/index.php/IJAgS/issue/view/17

[84]. Bhalerao, P.D. G.S. Gaikwad and S.R. Imade. Productivity and nutrient uptake of Bt-cotton as influenced by precision in application of irrigation water Indian Journal of Agronomy 2010,www.isa-india.in/html/journals/.../Volume\% 2056\%20_2011.pdf.

[85]. Bhalerao, P.D. P.W. Deshmukh, Godavari. S. Gaikwad And S.R. Imade. Response of Bt cotton (Gossypium hirsutum) to spacing and fertilizer levels. Indian Journal of Agronomy - Indian Society Of Agronomywww.isaindia.in/html/journals/.../Volume\%2057\%20_2012.pdf.

[86]. Buttar, G S S K Jalota, Anil Sood, Bharat Bhushan Yield and water productivity of Bt cotton as influenced by temperature under semi-arid conditions of north-western India: field and simulation study Indian Journal of Agricultural Sciences, 2012. 82 (1): 44-9.

[87]. Thind, HS., Yield and water use efficiency of hybrid Bt cotton as affected by methods of Drip irrigation under normal sowing, Archives of Agronomy and Soil Science 2012. 58(2):

[88]. Dilbaugh, Muhammad, I. Raza, S. Ahmad, M. N. Afzal, M. A. Mian, Efficiency of drip vs furrow irrigation system with variable plant density on cotton under southern Punjab climatic conditions Central Cotton Research Institute, Multan. Facing global cotton in the next decade. Abstract No. Oral-128

[89]. Prasad J. Kapur Tarun, Sandhar N. S., Majumdar G., Patil P. G., Shukla S. K. Jaiswal B. N., Patil A. B. Performance evaluation of spindle type cotton picker. Journal of Agricultural Engineering, 2007,44(1):38-42. epubs.icar.org.in/ ejournal/ index.php/ $\mathrm{JAE} /$ article/view/14448.

[90]. Nachane, R. P. Influence of quality attributes of individual bales on yarn quality in value addition Concurrent Session 6 Abstract No. Oral-26

[91]. Nagappa, H. and B. M. Khadi, Studies on composition of oil and fatty acid In Bt and non Bt cotton, Abstract No. Oral-28.

[92]. Zakaria M. S.,M. H. Mahmoud A. H. El-Guibali, Influence of potassium fertilization and foliar application of zinc and phosphorus on growth, yield components, yield and fiber properties of Egyptian cotton. Journal of Plant Ecology, 2012, 1 (4):259-270.

[93]. Gill, S.S, Identification of G. hirsutum genotypes suitable for mechanical picking. The need for dwarf, compact, early \& synchronously maturing genotypes are ...tmc.cicr.org.in/pdf/1.3-07-08.pdf · PDF file

[94]. Gwathmey, C.O. and R. M. Hayes, Ultra narrow row system of notill cotton production. Research Progress in Tenessey,www.ag.auburn.edu/auxiliary/nsdl/scasc/Proceedings/1996/Gwathmey. pdf

[95]. Baker, K. D., Hughs, S.E., McAlister, D.D., Mackey, J. Quality of spindle-picked cotton. American Society of Agricultural Engineers. 2004. Paper No. 041052.

[96]. Silvertooth, J. C., Recent yield and fiber micronaire tendencies for upland cotton in Arizona. Arizona Cotton Report, 2001, The University of Arizona College of Agriculture and LifeSciences,index athttp://ag.arizona.edu/ pubs/ crops/az1224/

[97]. Meredith Lindsay, C. Campbell Ian Rochester, Daniel K. Y. Tan, Efficacy of foliar fertilization in cotton, University of Sydney, University of Sydney, Australia, 2011. 1686

[98]. Jadhav, S.B. and K. R. K. Iyer, Differential speed setting facility for roller and beater in gins for higher ginning rates, Page No.93. 
[99]. Lackey, Jerry, USDA forecasting highest U. S. cotton yield in history. San Angelo Standard Times, 2007, Western Farm Press, Nov. 28, 2007 10:11am

[100] Anonymous, 2013. Oversupply triggers price war among Bt hybrid cotton seed makers http://www.indianbrokersassociation.com/market/oversupply-triggers-price-war-among-bt-hybrid-cotton-seed-makers-978.php

[101] Cotton News » India: States Plan To Promote Cotton Outputhttp://cottonmarketnews.com/2012/07/04/india-states-plan-to-promotecotton-output/

[102] Kathage $e^{1}$ J. and Matin Qaim 2012. Economic impacts and impact dynamics of Bt cotton in India http://www.pnas.org/content/early/ 2012/06/25/ 1203647109\# corresp-1

[103]. Williams, D. and D.Sood, 2013. GAIN News 2013. Global Agriculture Information Network News.

[104] Khadi, B. M. K. R. Kranthi and K. C. Jain 2007 Impact of Bt-cotton on Agriculture in India. The World Cotton Research Conference-4 (September 10-14, 2007).

[105] Frisvold, G.B. Reeves,J.M. 2007. Economy-wide Impacts of Bt Cotton. Proceedings of the Beltwide Cotton Conferences, January 2007 https://www.icac.org/cotton_info/tis/biotech/documents/otherdocs/gtap_beltwide.pdf

[106] PTI, 2013. India to export 20 lakh bales of cotton to B'desh in 2013-14. The Economic Times Aug 19, 2013, 06.38PM IST http://articles.economictimes.indiatimes.com/2013-08-19/news/41425334_1_cotton-exports-cotton-season-bales 